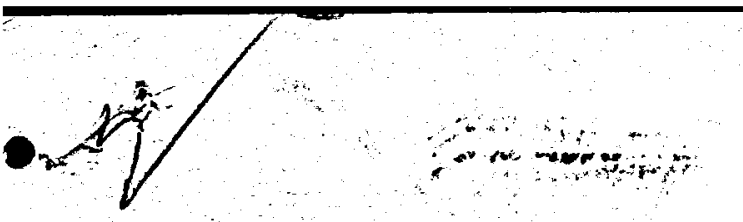

\title{
GEOCHEMISTRY OF THE COLADO GEOTHERMAL AREA, PERSHING COUNTY, NEVADA
}

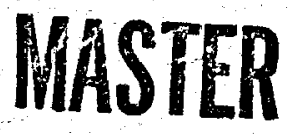

by

Odin D. Christensen

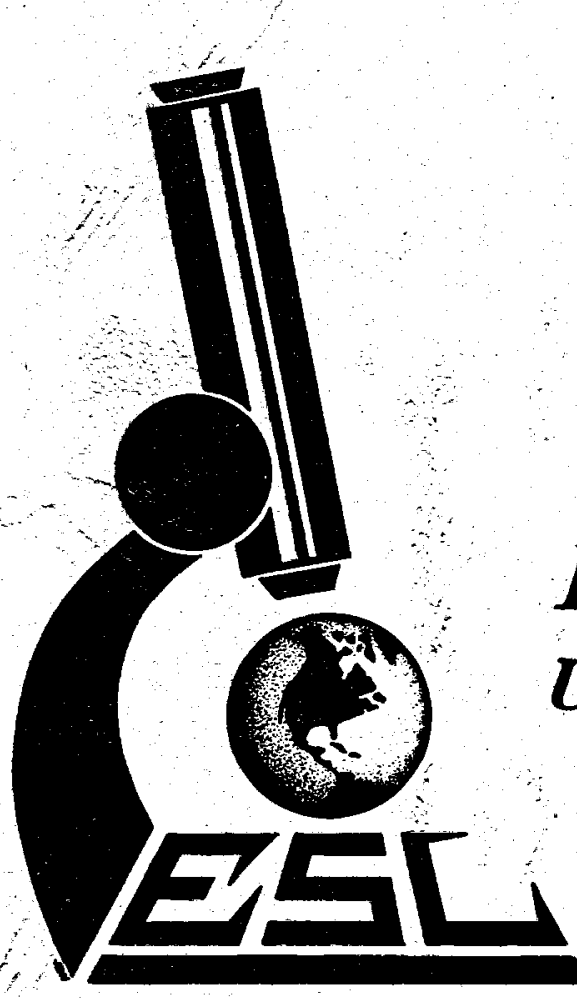

July 1980

\section{EARTH SCIENCE LABORATORY} University of Utah Research Institute Salt Lake City, Utah

U.S. Department of Energy

Division of Geothêrmal Energy

Under Contract No. DE-ACO7-80ID12079 


\section{GEOCHEMISTRY OF THE COLADO GEOTHERMAL AREA, PERSHING COUNTY, NEVADA}

by

Odin D. Christensen

July 1980

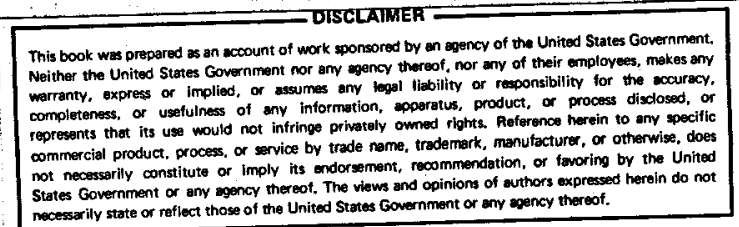

BISTRIBUTION OF THIS DOCUMENT IS UNLIMIFED

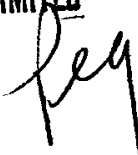




\section{DISCLAIMER}

This report was prepared as an account of work sponsored by an agency of the United States Government. Neither the United States Government nor any agency Thereof, nor any of their employees, makes any warranty, express or implied, or assumes any legal liability or responsibility for the accuracy, completeness, or usefulness of any information, apparatus, product, or process disclosed, or represents that its use would not infringe privately owned rights. Reference herein to any specific commercial product, process, or service by trade name, trademark, manufacturer, or otherwise does not necessarily constitute or imply its endorsement, recommendation, or favoring by the United States Government or any agency thereof. The views and opinions of authors expressed herein do not necessarily state or reflect those of the United States Government or any agency thereof. 


\section{DISCLAIMER}

Portions of this document may be illegible in electronic image products. Images are produced from the best available original document. 


\section{NOTICE . .}

This report was prepared to document work sponsored by the United States Government. Neither the United States nor its agent, the United States Department of Energy, nor any Federal employees, nor any of their contractors, subcontractors or their employees, makes any warranty, express or implied, or assumes any legal liability or responsibility for the accuracy, completeness, or usefulness of any information, apparatus, product or process disclosed, or represents that its use would not infringe privately owned rights.

\section{NOTICE}

Reference to a company or product name does not imply approval or recommendation of the product by the University of Utah Research Institute or the U.S. Department of Energy to the exclusion of others that may be suitable. 
ABSTRACT . . . . . . . . . . . . . . . . .

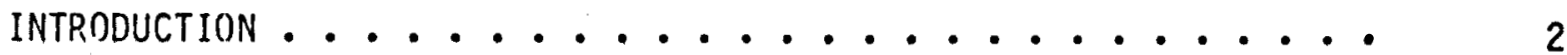

ANALYTICAL TECHNIQUES .............................. 4

DISCUSSION . . . . . . . . . . . . . . . 5

Geology ...................... 5

As, Hg, Li and Be Distributions.............. 11

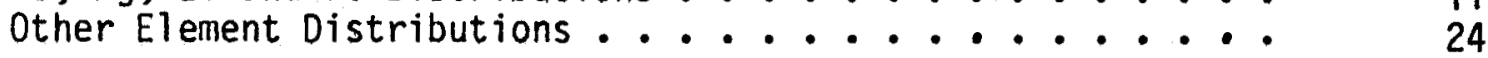

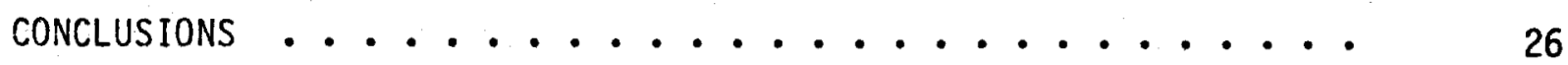

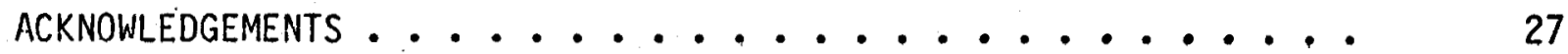

REFERENCES ....................... . . . . . . 29

APPENDIX: Summary of Geochemical Data . . . . . . . . 31

FIGURES

Figure 1 Index map of gradient hole locations ....... 3

Figure 2 An example of the selection of threshold values using probability graphs ............. 6

Figure 3 Generalized geology of the Colado geothermal area . . 8

Figure 4 Generalized geologic cross sections .......... 10

Figure 5 Arsenic distribution in drill cuttings ....... 12

Figure 6 Mercury distribution in drill cuttings ........ 13

Figure 7 Lithium distribution in drill cuttings . . . . . . 14

Figure 8 Beryllium distribution in drill cuttings . . . . . 15

Figure 9 Temperature distribution in temperature gradient holes. $\quad 16$

Figure 10 Arsenic distribution in drill cuttings along two

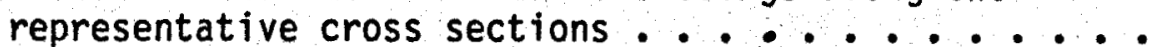

Figure 11 Mercury distribution in drill cuttings along two representative cross sections .......... 
Figure 12 Lithium distribution in dri1l cuttings along two representative cross sections..........

Figure 13 Beryllium distribution in drill cuttings along two representative cross sections.........

Figure 14 Temperature distribution in two representative

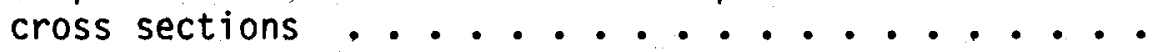




\section{ABSTRACT}

Nultielement geochemical analysis of drill cuttings from 18 shallow and 2 intermediate-depth temperature gradient holes outlines an area of anomalous geochemistry related to the fluid flow and temperature distribution within the Colado geothermal area. The concentrations of $\mathrm{Hg}, \mathrm{As}, \mathrm{Li}$, and Be belong to more than one statistical population and provide the clearest expression of hydrothermal processes. Enrichments of these four elements define anomalous zones which are spatially coincident with a measured temperature anomaly. The spatial distribution suggests that thermal fluid rises into alluvium in the vicinity of a major Basin and Range fault to depths of 200-400 feet (60$120 \mathrm{~m}$ ), then flows laterally within shallow alluvial aquifers down the local hydrologic gradient. As the fluid cools, $\mathrm{Li}, \mathrm{Be}, \mathrm{As}$, and $\mathrm{Hg}$ are deposited in response to changing physical and chemical conditions. As and Be appear to be deposited early in higher temperature zones; Li begins to deposit early but forms a rather dispersed geochemical anomaly; $\mathrm{Hg}$ is anomalous throughout the entire geothermal area but is concentrated in a shallow halo above the As and Be anomalies. The distributions suggest that the entry of thermal fluids from depth into the alluvium is spatially restricted to a small area and that the larger area of the observed thermal anomaly is due to the flow of warm fluid within shallow aquifers. 


\section{INTRODUCTION}

The Colado geothermal area lies in south-central Pershing County, Nevada, approximately 8 miles northeast of Lovelock (Figure 1). The geothermal potential of the area for electric power production is currently being evaluated by Getty $0 i 1$ Company in cooperation with the Division of Geothermal Energy of the U. S. Department of Energy.

During 1979-80, 18 shallow and 2 intermediate-depth temperature-gradient holes were drilled within the area (Fig. 1). Cuttings from these holes were subsequently released for study to the University of Utah Research Institute, Earth Science Laboratory Division (ESL) through the DOE/DGE Industry Coupled Program. This study is part of an ongoing case study of the Colado geothermal area by ESL.

Multielement geochemical analysis of the drill cuttings has been performed in order to more closely define the position and extent of the geothermal resource. Recent studies demonstrate that the trace element geochemistry of well cuttings from geothermal systems can be a useful exploration guide, particularly in the early stages of geothermal development (Banford, 1978; Bamford and others, 1980; Bamford and Christensen, 1979; Christensen and others, 1980b). Trace element distributions developed as a consequence of temperature gradients and fluid flow within a geothermal system place constraints on the possible geometry of the present system and may provide insight into its thermal and convective history. 


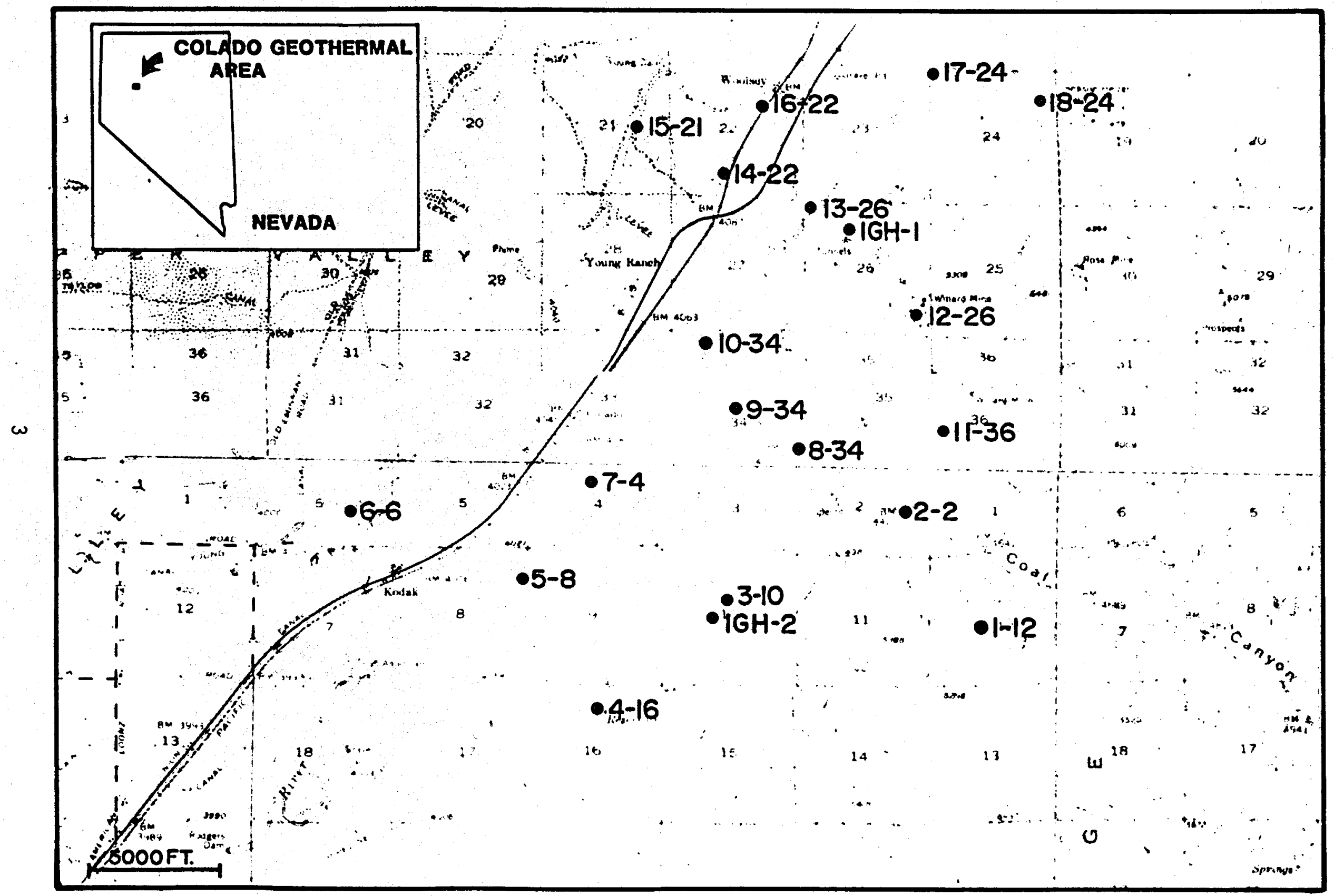

Figure 1. Index map of gradient hole locations. 


\section{ANALYTICAL TECHNIQUES}

Samples were prepared for analysis by washing all individual 10-foot interval samples, compositing samples over 100-foot intervals, and pulverizing to less than 270 mesh in a SPEX tungsten carbide shatterbox. Pulverized samples were dissolved by a four acid digestion procedure (Christensen and others, 1980a).

Samples were analyzed for 37 elements by inductively coupled plasmaatomic emission spectroscopy (ICP-AES) using an Applied Research Laboratories inductively coupled plasma quantometer (ICPQ) Model QA-137 in the ESL geochemical laboratory. Elements determined by ICP-AES were $\mathrm{Na}, \mathrm{K}, \mathrm{Ca}, \mathrm{Mg}$, $\mathrm{Fe}, \mathrm{Al}, \mathrm{Si}, \mathrm{Ti}, \mathrm{P}, \mathrm{Sr}, \mathrm{Ba}, \mathrm{V}, \mathrm{Cr}, \mathrm{Mn}, \mathrm{Co}, \mathrm{Ni}, \mathrm{Cu}, \mathrm{Mo}, \mathrm{Pb}, \mathrm{Zn}, \mathrm{Cd}, \mathrm{Ag}, \mathrm{Au}, \mathrm{As}$, Sb, Bi, U, Te, Sn, W, Li, Be, B, Zr, La, Ce, and Th. Specifics of the analytical instrumentation and procedures, as well as an evaluation of the quality of analyses are summarized in Christensen and others (1980a). In addition, As was determined on each sample solution by a colorimetric procedure, and $\mathrm{Hg}$ was determined in solid samples by gold film mercury detector.

In order to distinguish chemical variations resulting from geothermal processes from the dispersion of analytical values expected in natural normal or lognormal background geochemical populations, analytical values were partitioned graphically through the use of cumulative probability plots following the procedures described by Sinclair $(1974,1976)$ and Lepeltier (1969). The method permits estimation of population parameters for mixed distributions of two or more populations. It involves dissection of the 
cumulative frequency distribution curve using probability graph paper. For this type of graph, the cumulative frequency distribution curve of a normal distribution is a straight line from which the mean and standard deviation of the distribution can be estimated. For polymodal distributions, the cumulative frequency distribution curve can be dissected into two or more lines from which the parameters of each distribution can be estimated. An example of this procedure for Colado arsenic data is presented as Figure 2. Bold contour values presented in Figures 5 through 8 and 10 through 13 have been determined by this method, and thus represent statistically determined thresholds separating distinct geochemical populations. Other contours have been added for clarity.

of the elements investigated, $\mathrm{Hg}, \mathrm{As}, \mathrm{Li}$, and Be appear to belong to more than one population and are regularly zoned about the present geothermal system. The distributions of these elements are, in general, largely independent of rock type and consequently provide the clearest expression of recent hydrotherinal activity. Data for these elements are presented graphically in this report as Figures 5 through 8 and 10 through 13 ; a data, summary for all elements are included in the Appendix and complete data is available on open-file at ESL.

\section{DISCUSSION}

Geology

The geology and mineral deposits of Pershing County, Nevada, have been reviewed by Johnson (1977). Reports by Coonrad (1957) and Osterling (1960) describe the geology and mineral deposits in the Colado area more specifi- 

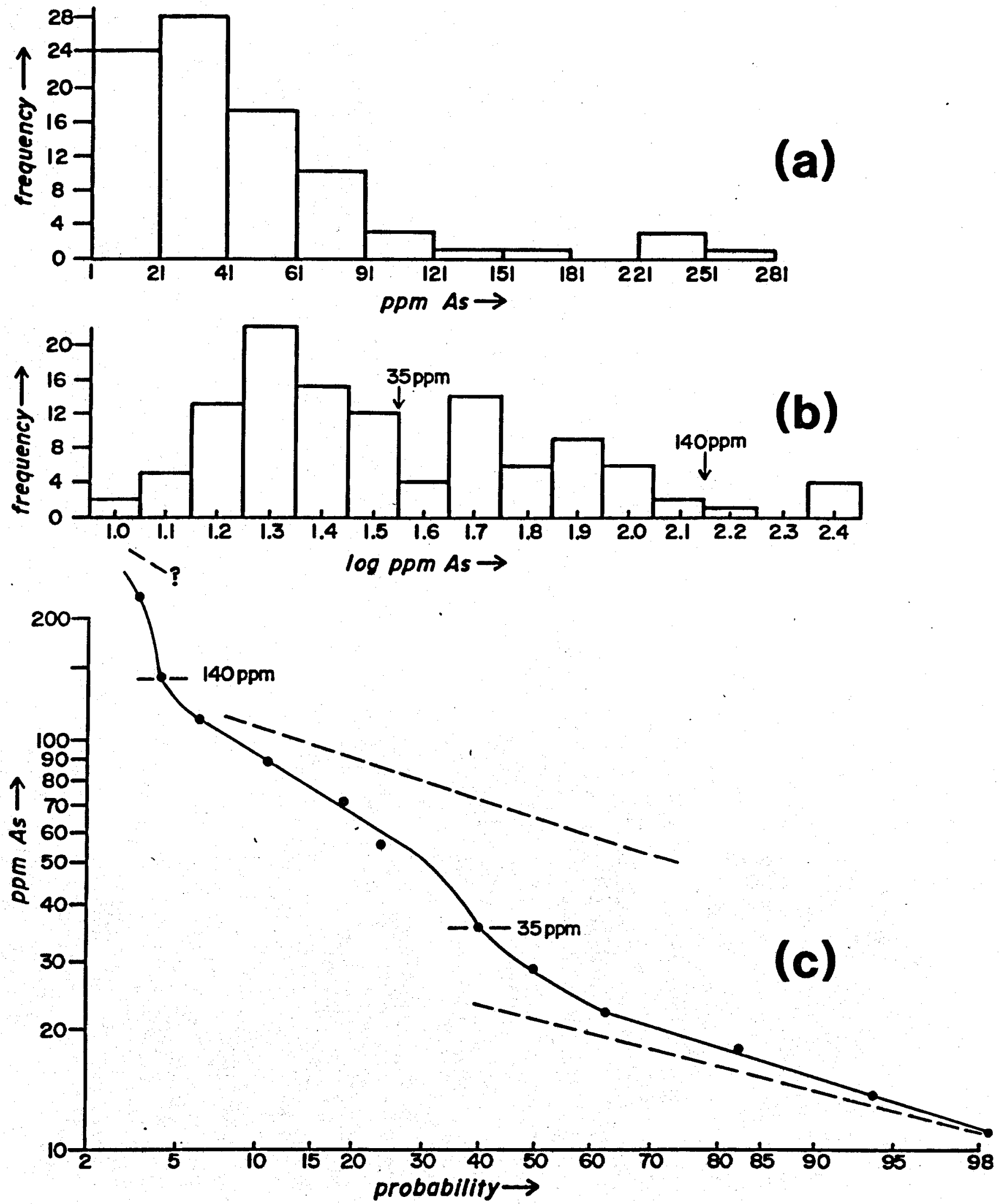

Figure 2. An example of the selection of threshold values using probability graphs: (a) distribution histogram, arithmetic scale; (b) distribution histogram, logarithmic scale; (c) cumulative frequency distribution on logarithmic probability scale. Threshold values of $35 \mathrm{ppm}$ and $140 \mathrm{ppm}$ effectively separate three populations of As analytic values. 
cally. Detailed geologic mapping and other investigations within the Colado geothermal area are currently in progress by Bruce Sibbett of ESL in conjunction with the DOE/DGE Industry Coupled Program.

The Colado geothermal area straddles the western flank of the West Humboldt Range adjacent to the Humboldt River Valley (Figure 1). Rocks exposed within the thermal area are predominantly clastic Mesozoic sedimentary rocks, Tertiary rhyolitic to dacitic tuffs and flows, and Quaternary alluvial deposits (Figure 3 ). The rocks have been subjected to several periods of deformation characterized by large-scale folding, thrust faulting, and Basin and Range normal faulting. Antimony, copper, and precious metal deposits of the Willard District were mined in the eastern portion of the area. Indeed, high temperatures and stean encountered in precious metal exploration drill holes and trenches were in part responsible for arousing initial interest in the geothermal potential of the area.

The eastern portion of the geothermal prospect is largely underlain by sedimentary rocks of Triassic and Jurassic age assigned to the Auld Lang Syne Group. Predominant lithologies are shale, sandstone, quartzite, and limestone that in general strike northwest and dip southwest. To the south, Jurassic gypsum sequences cover the clastic sediments in a series of imbricate thrust sheets. Tertiary volcanic and pyroclastic rocks overlie the sedimentary rocks throughout the district.

Antimony, gold, and copper deposits are developed along numerous northeast- and northwest-striking quartz veins and silicified zones within the metasedimentary rocks. The most extensive mining development has been at the 


\section{EXPLANATION}

QUATERNARY

[Q]-Humboldt river channel and flood plain deposits लa]-Alluvial fons and colluvlum

[0]-Eolian sond and slit, octive and inactive

पOD-Lake Lahonton deposits

[व1b-Lake shore deposits : beach, splts, deltos TERTIARY

CTS-Alluvlum

\section{[1]-Tuff}

[I]-Rhyolite, intrusive dome or plus MESOZOIC

[MID-Limestone

[MS:-Slate, argllilite

- Thrust foult, feeth on upper plate

- Fault, doshed where inferred

- Confact, dashed where inferred

- Drill hole location
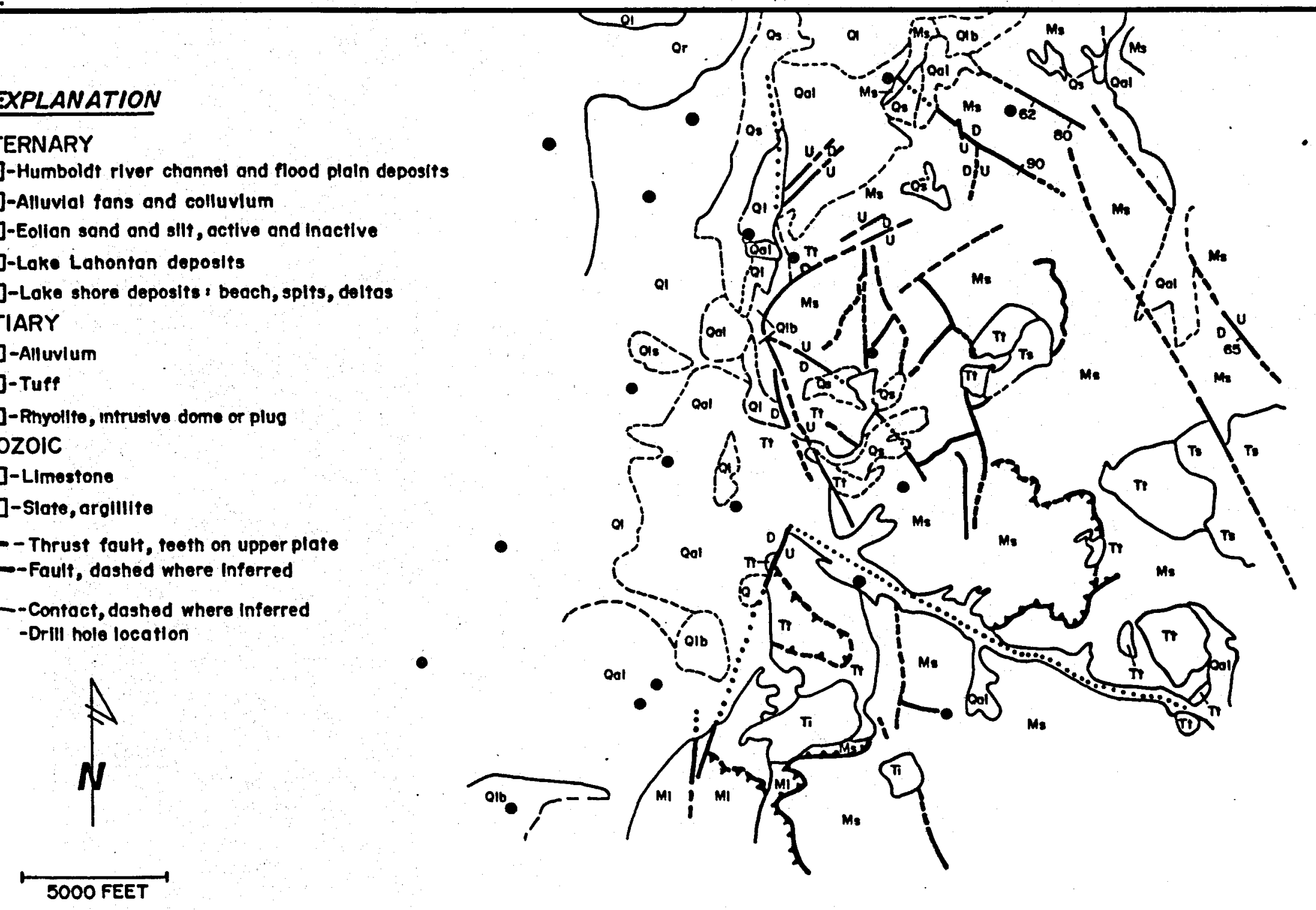

(after Sibbett and Bullett, 1980)

Figure 3. GENERALIZED GEOLOGY OF THE COLADO AREA PERSHING COUNTY, NEVADA 
northern body of the Johnson-Heizer mine (S19, T28N, R33E) along a vein striking $N 45 \mathrm{~W}$ and dipping $60^{\circ} \mathrm{SW}$. Northeast and east-west-trending structures control mineralization at the Willard group of gold mines (S25-26, T28N, R32E) (Osterling, 1960).

Most of the area is covered by unconsolidated alluvial fan, lake bottom, eolian, and flood plain deposits (Figure 3 ). Shoreline features of Pleistocene Lake Lahontan, including calcareous tufa deposits, were developed along the flanks of the West Humboldt Range. Much of the alluvial material is porous and serves as aquifers for shallow groundwater in the Humboldt River Valley (Cohen, 1964, 1966).

Basin and Range block faulting is represented by normal faults along the margins of the West Humboldt Range. The inferred positions of some of these faults are indicated on Figure 3 after Osterling (1960), Johnson (1977), Sibbett (1980, personal communication), and Mackelprang (1980, personal communication). Magnetic and gravity data suggest the presence of several additional parallel faults beneath the alluvial cover to the west of the range (Mackelprang, personal communication). It seems likely that these deep structures serve as important controls on the hydrology of the geothermal system.

The presence of anomalously warm temperatures at shallow depths in the Colado area has been known for some time. Christen (1920) reported water so hot at a depth of 10 meters in a shaft (NE $1 / 4$ SE1/4 S27, T28N, P.32E) that the shaft had to be abandoned (Osterling, 1960) and Getty 0il Company encountered steam in a shallow mineral exploration drill hole in Section 26, T28N, R32E. 


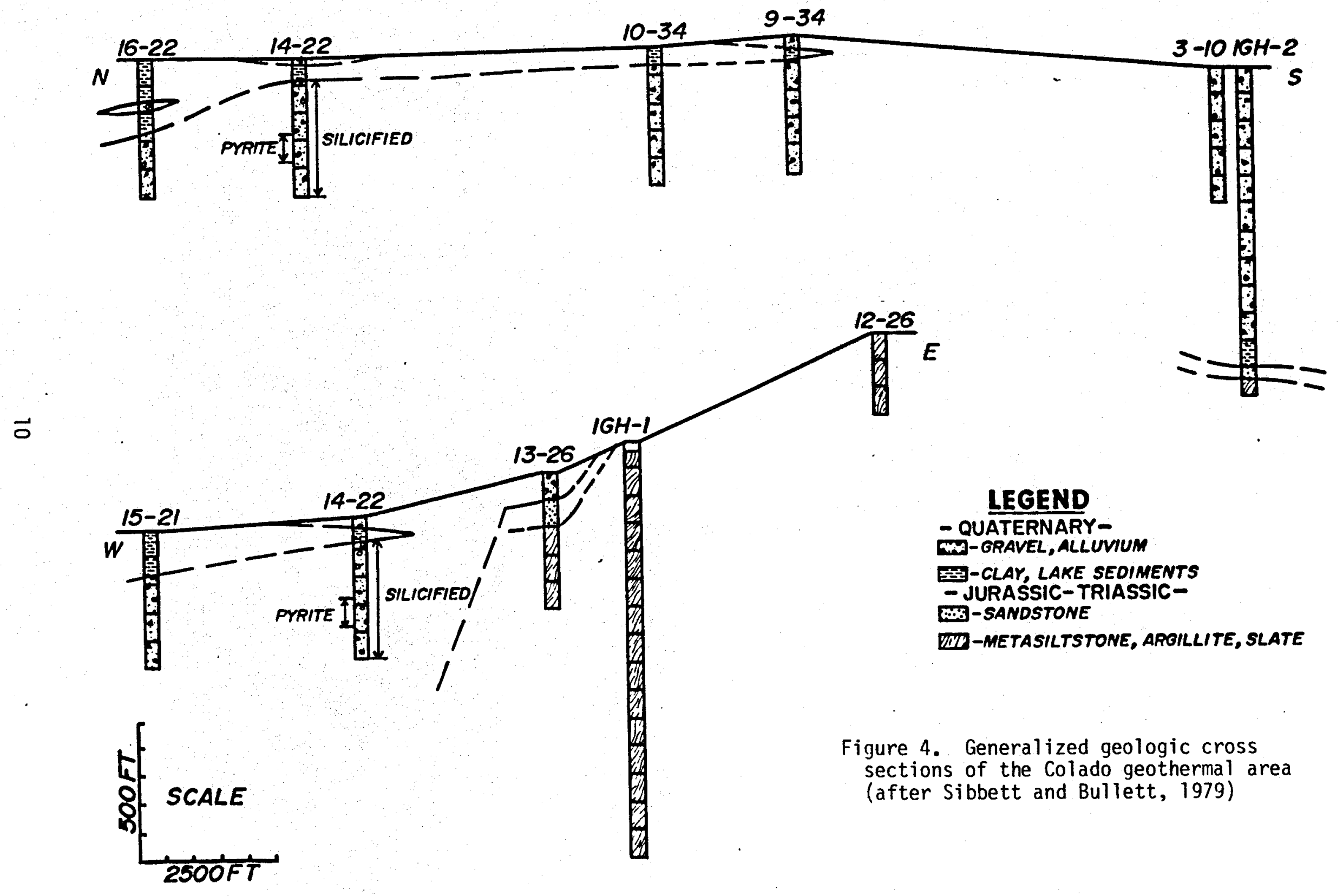


Alteration, apparently related to therinal fluids, occurs in the section penetrated by the 500-foot gradient hole 14-22 (Figures 1,4) where alluvium is silicified at depths from 100 feet to total depth $(30-150 \mathrm{~m})$ and pyritized in the approximate interval 300 to 400 feet $(90-120 \mathrm{~m})$.

As, $\mathrm{Hg}, \mathrm{Li}$, and Be Distribution

As, $\mathrm{Hg}, \mathrm{Li}$, and Be are comnonly enriched in thermal fluids (Ellis and Mahon, 1977; Weissberg and others, 1979) and have been shown to form characteristic dispersion patterns about other hot-water geothermal systems (Bamford, 1978; Capuano and Moore, 1980; Barnford and others, 1980, Christensen and others, 1980b). The distributions of these elements in plan sections at five $100-$ foot $(30 \mathrm{~m})$ depth intervals (Figures $5-8)$, and in two representative cross sections (Figures 10-13) can be compared with the measured temperatures in the same sections (Figures 9 and 14). The greatest temperatures observed in the 20 gradient holes, up to $113^{\circ} \mathrm{C}$, were measured in hole 14-22. In this hole, as well as in several others $(5-8,7-4,13-26$, and 16-22), the maximuil temperatures are encountered at less than total depth, strongly suggesting that thermal fluids are rising into the alluvium and flowing laterally through shallow aquifers at depths of $200-400$ feet $(60-120 \mathrm{~m})$. The spatial distributions of several elements bear close correspondence with the temperature profile.

The numerical and spatial distributions of $\mathrm{As}$ and $\mathrm{Hg}$ are the most instructive. The numerical distribution of As concentrations strongly suggests the presence of three distinct geochemical populations with threshold concentrations between them of 35 and $140 \mathrm{ppm}$ (Fig. 2). The greatest concen- 


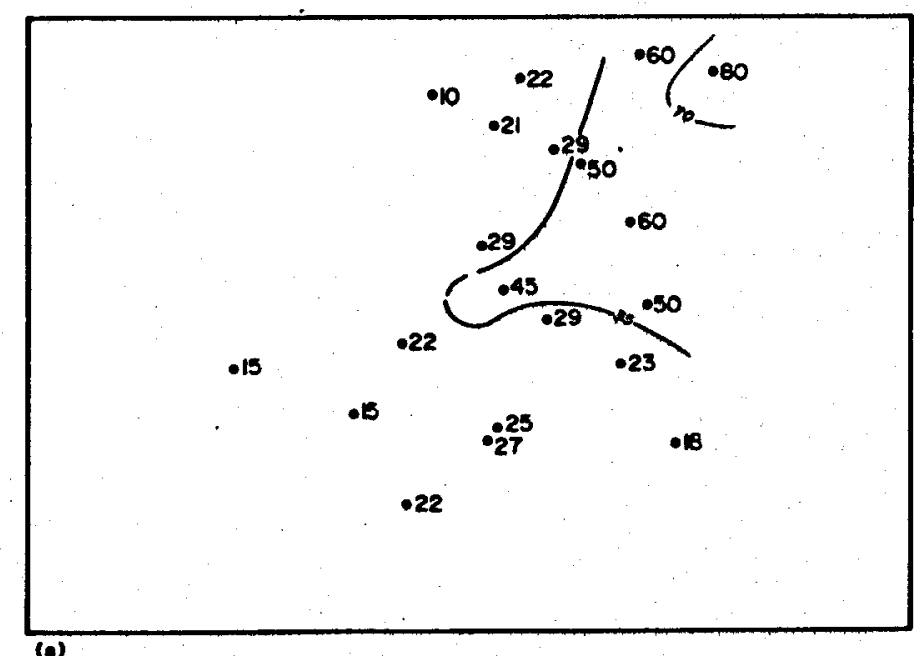

(a)
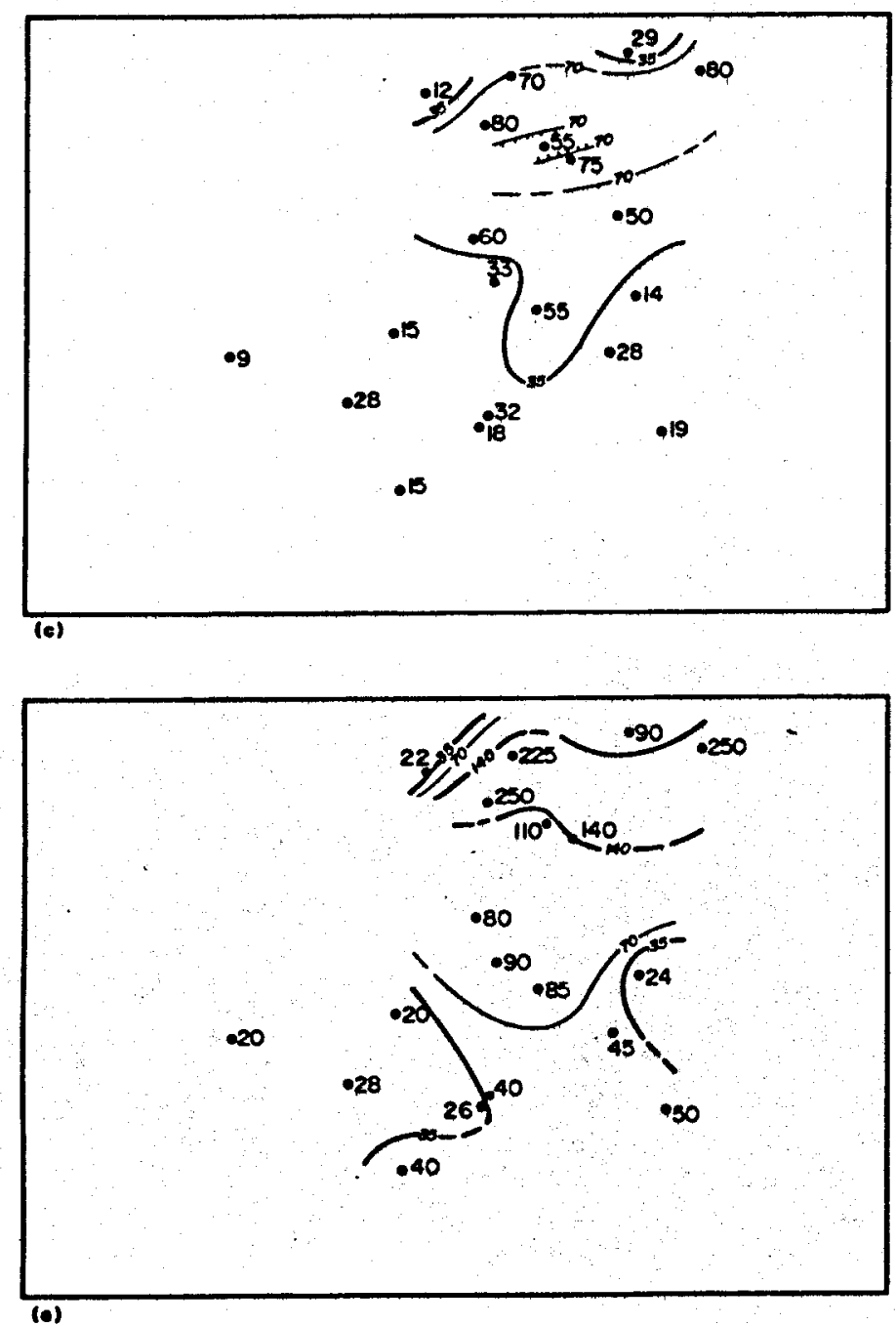
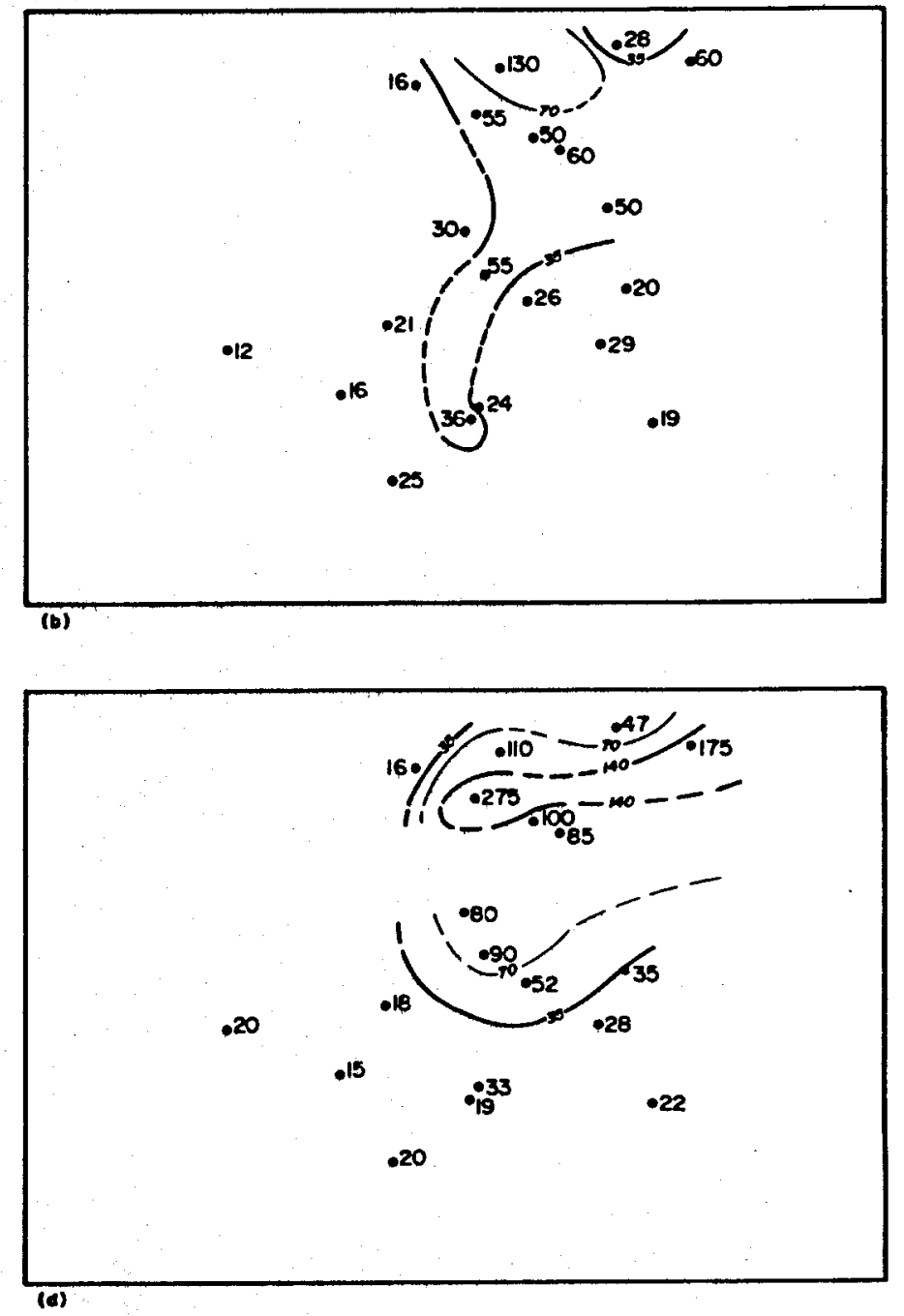

Figure 5. Arsenic distribution in drill cuttings (a) 0-100 feet, (b) 100-200

feet, (c) 200-300 feet, (d) 300-400 feet, (e) 400-500 feet. 

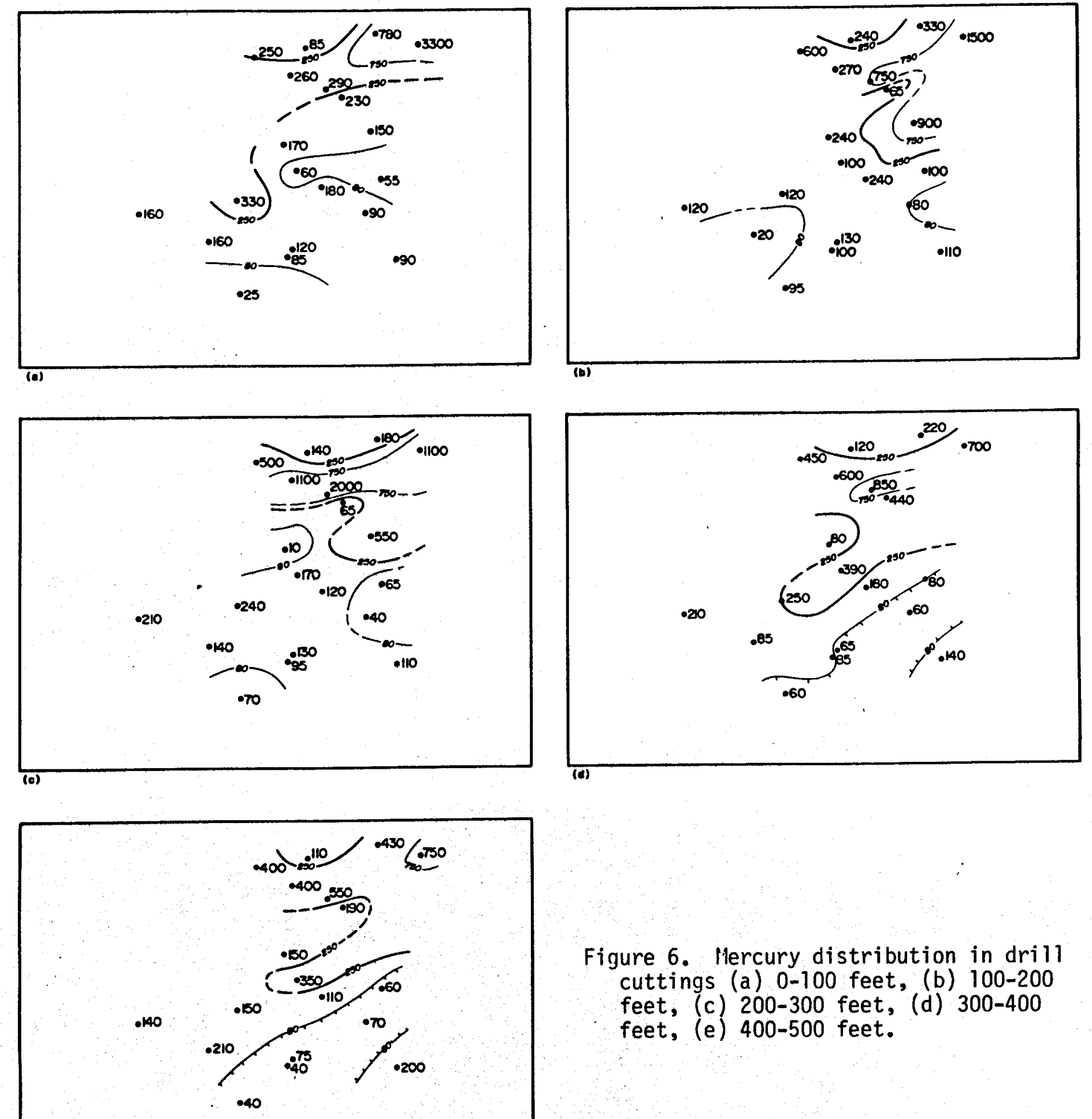

Figure 6. Hercury distribution in drill cuttings (a) 0-100 feet, (b) 100-200 feet, (c) 200-300 feet, (d) 300-400 feet, (e) 400-500 feet. 

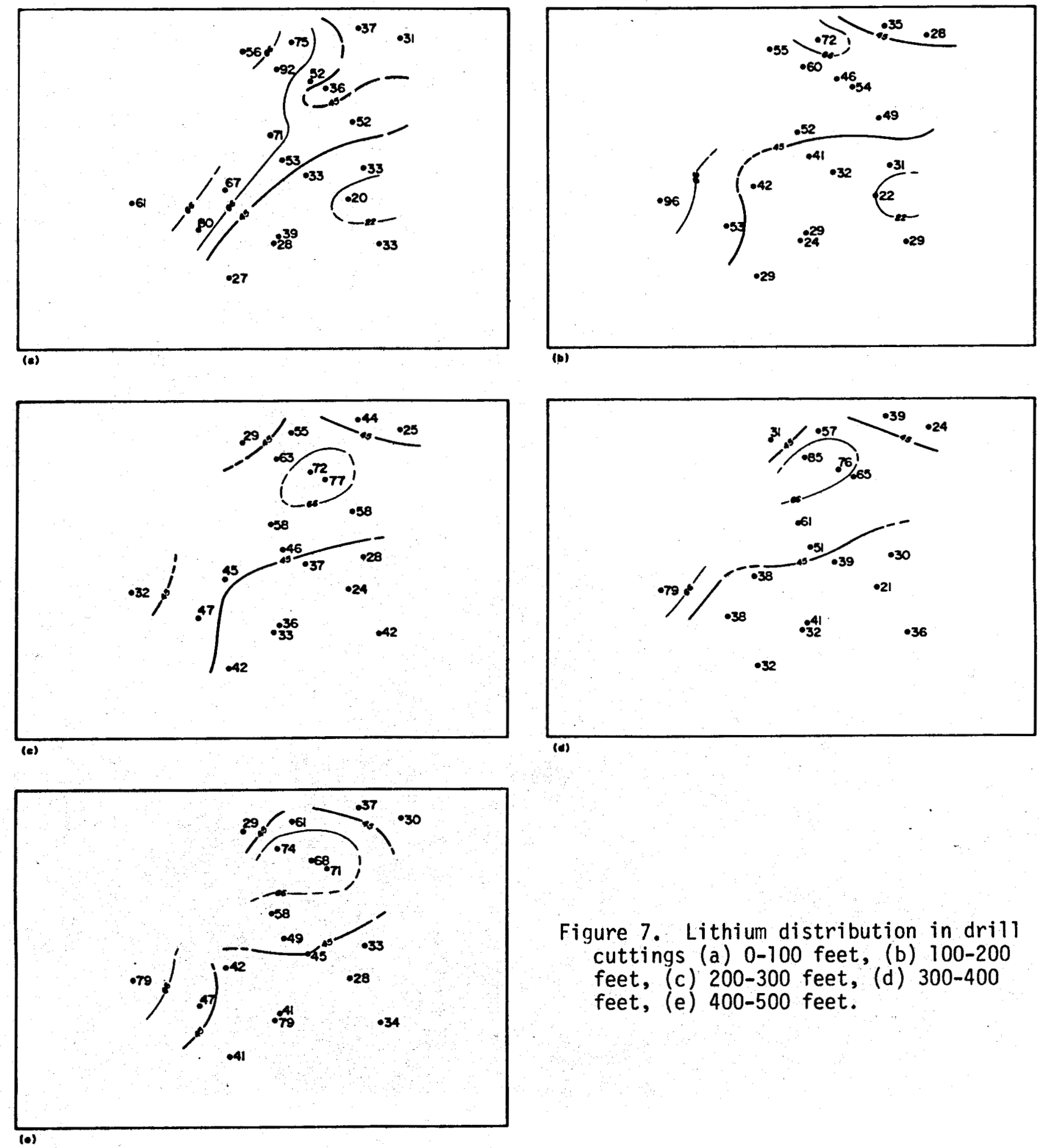

Figure 7. Lithium distribution in dri11 cuttings (a) 0-100 feet, (b) $100-200$ feet, (c) $200-300$ feet, (d) $300-400$ feet, (e) 400-500 feet. 

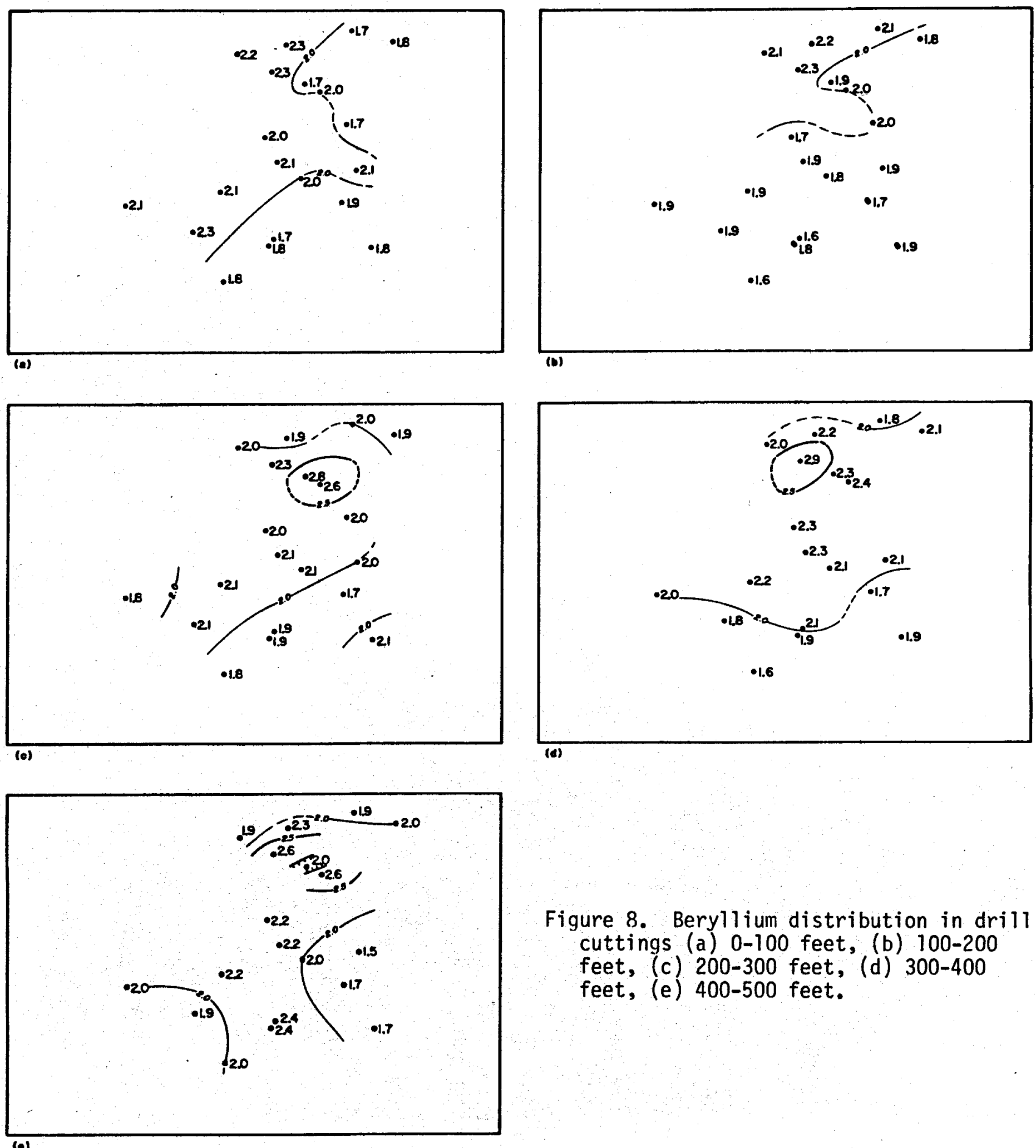

Figure 8. Beryllium distribution in drill cuttings (a) $0-100$ feet, (b) 100-200 feet, (c) 200-300 feet, (d) 300-400 feet, (e) 400-500 feet. 


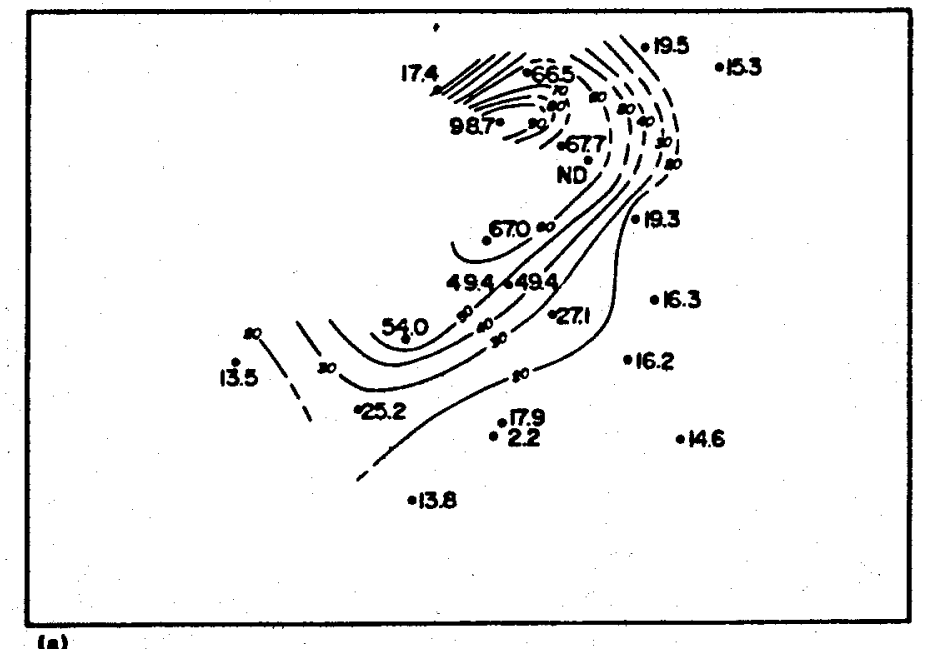

(a)
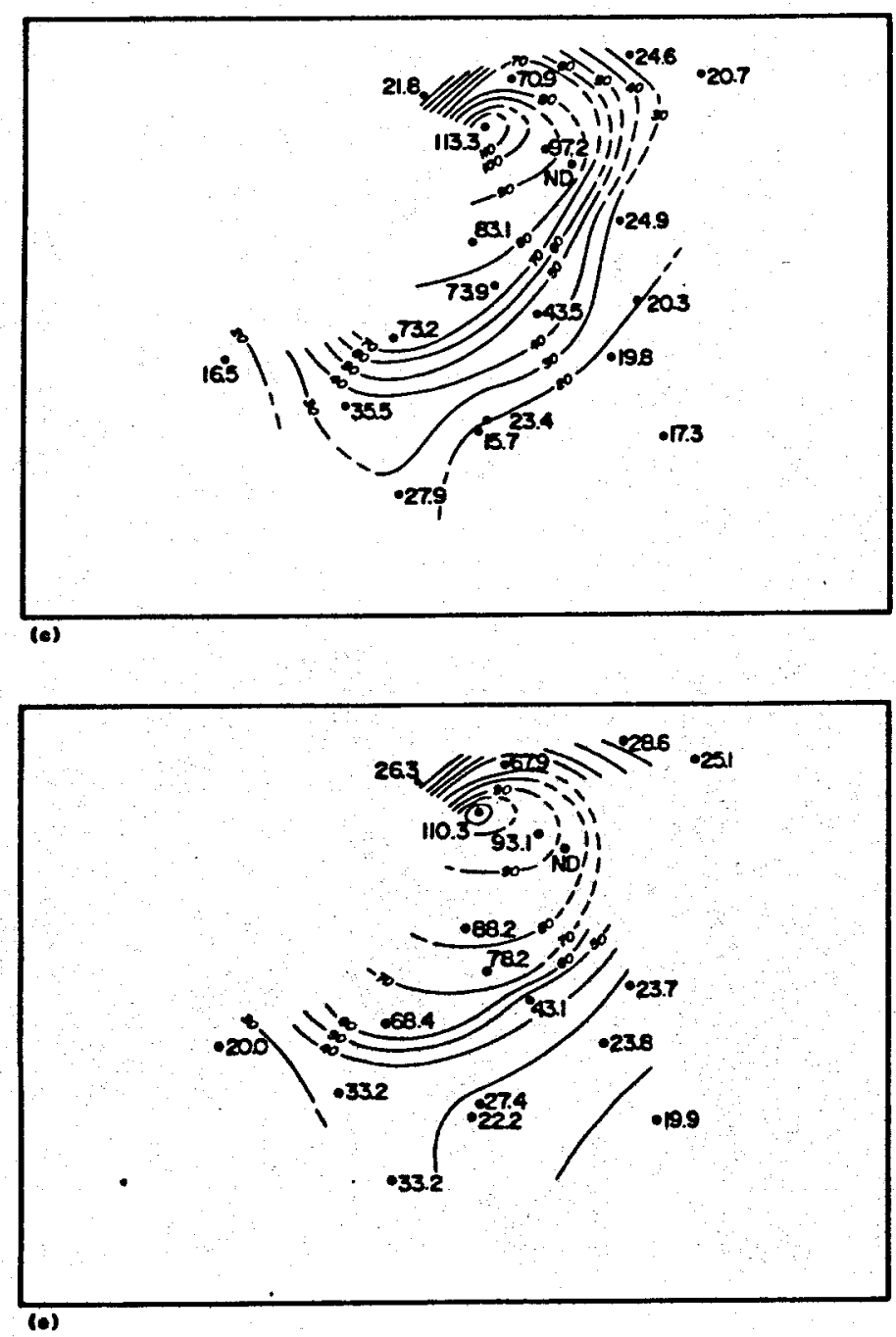

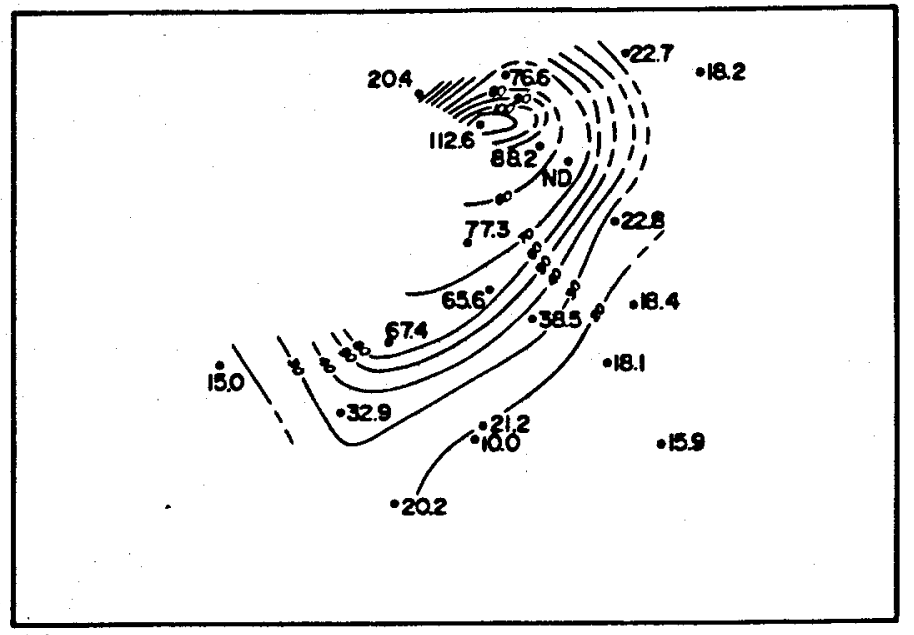

(b)

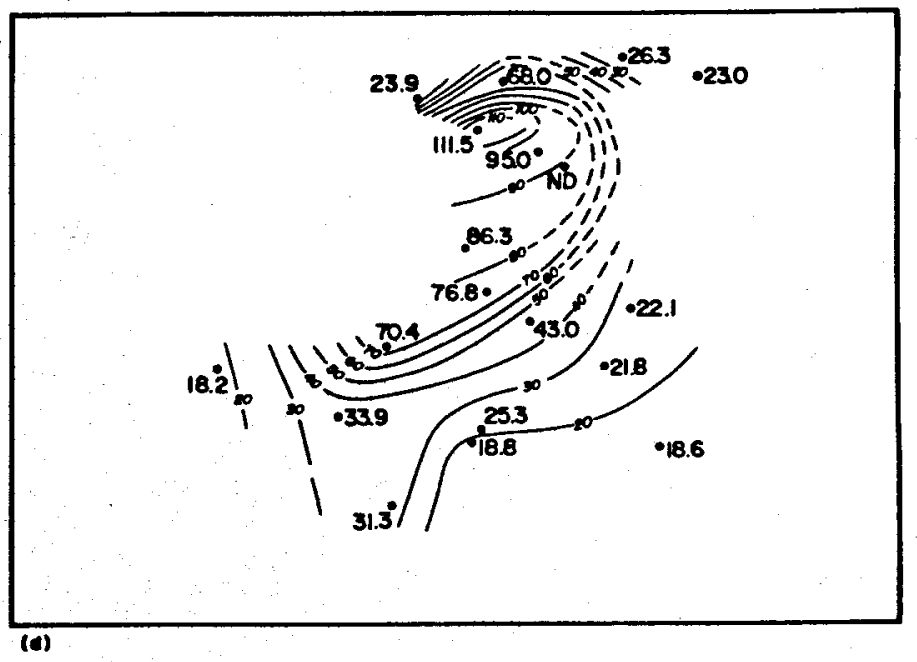

Figure 9. Temperature distribution in temperature gradient holes (a) 100 feet, (b) 200 feet, (c) 300 feet (d) 400 feet, (e) 500 feet. 

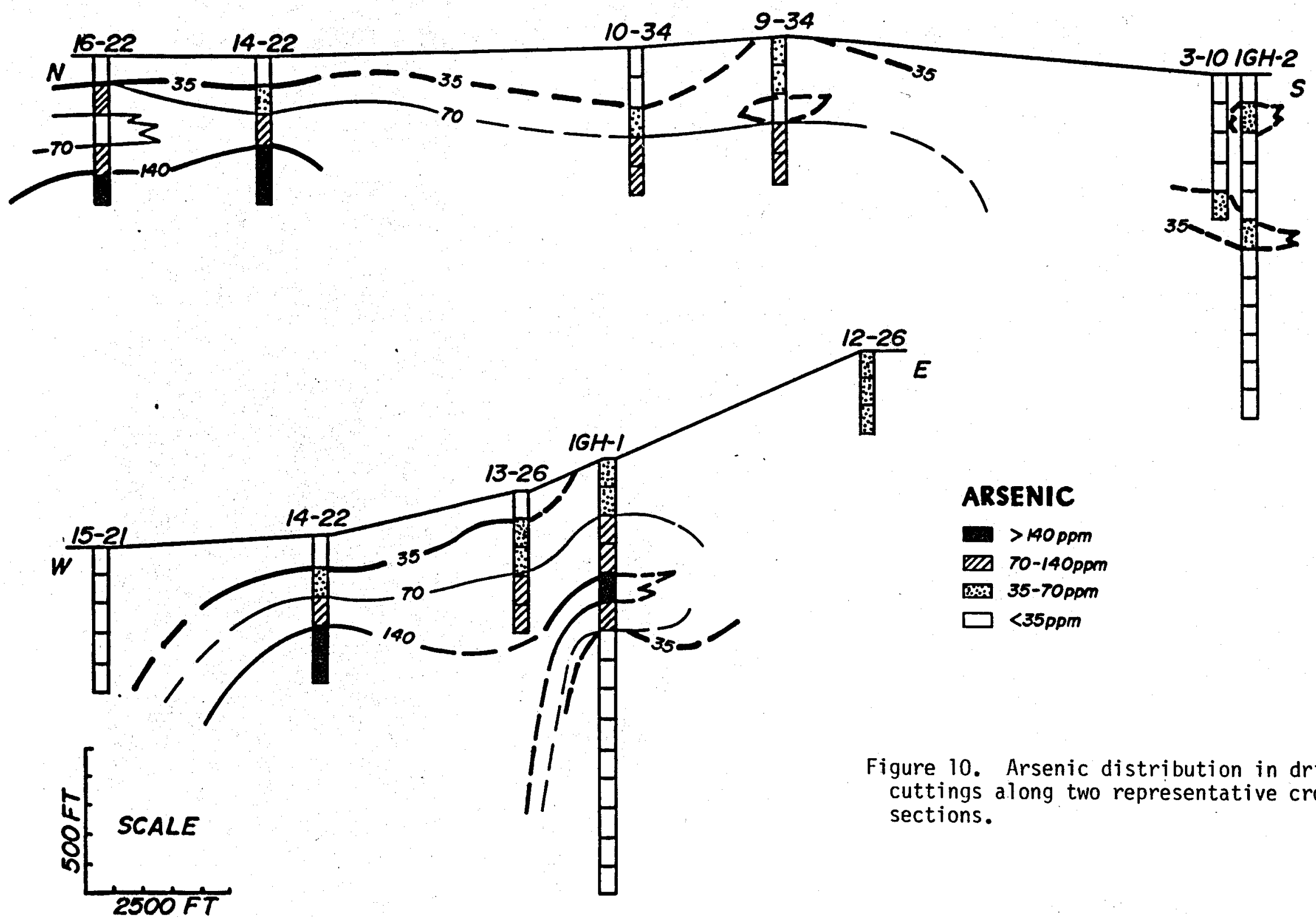

ARSENIC

a $>140 \mathrm{ppm}$

70-140ppm

50: 35-70 ppm

$\square<35 p p m$

Figure 10. Arsenic distribution in drill cuttings along two representative cross sections. 


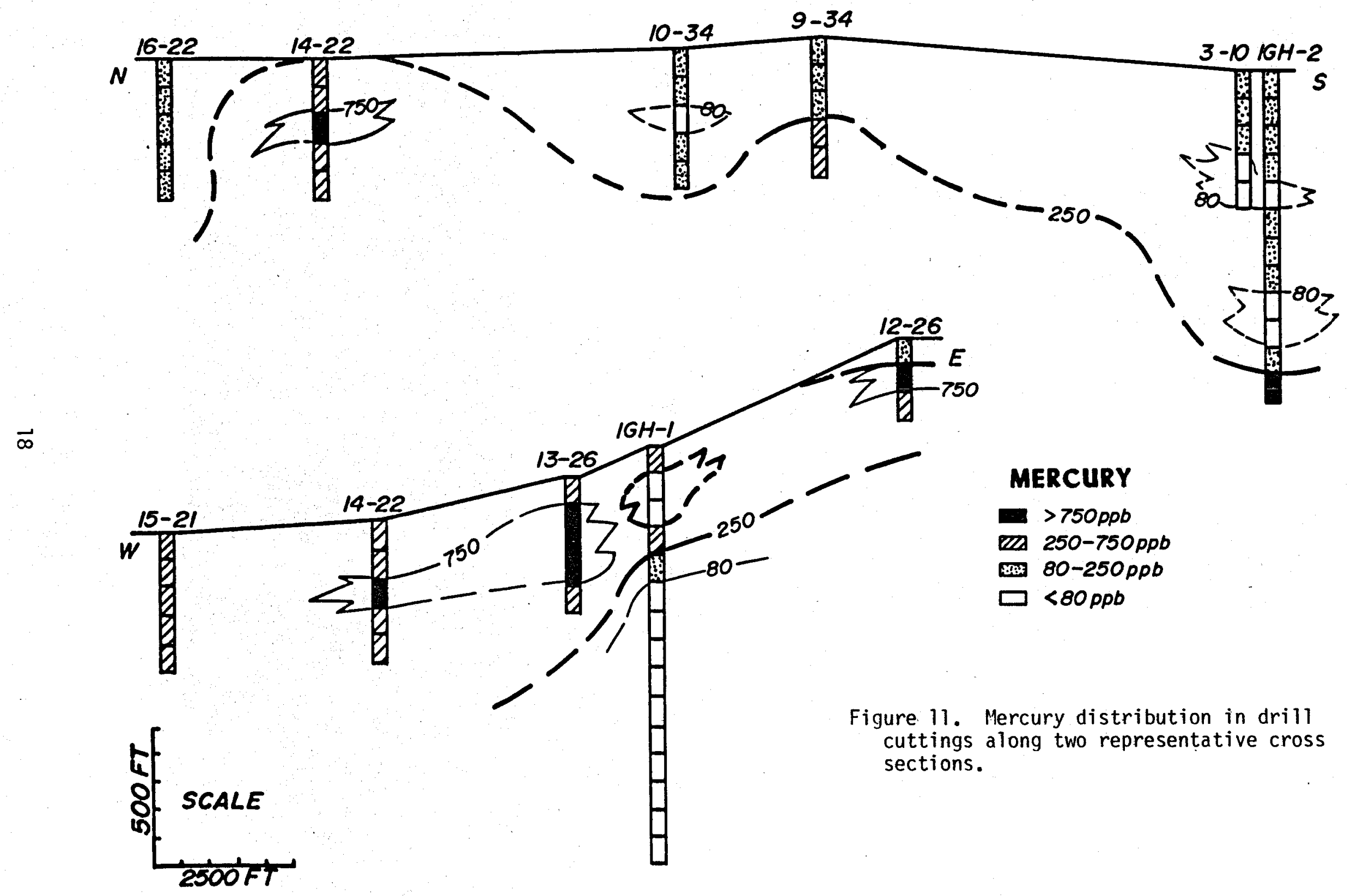




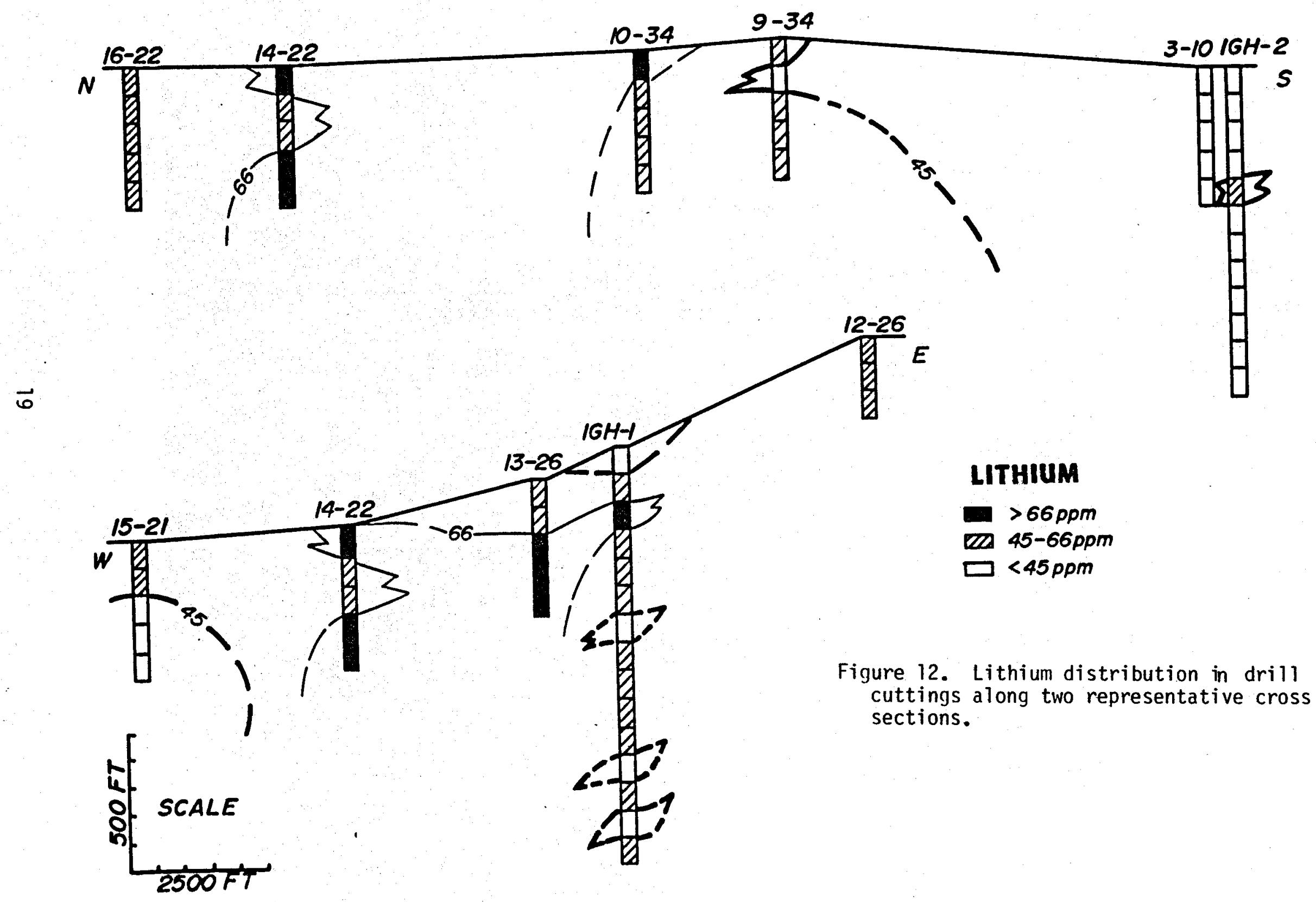




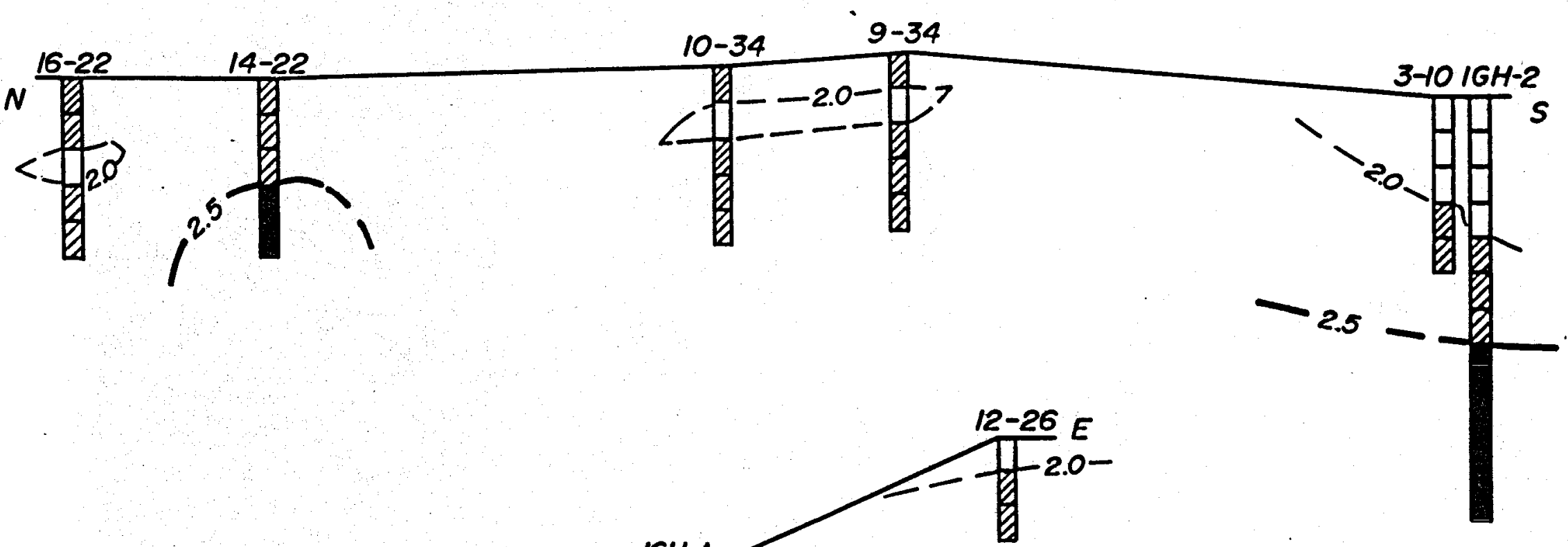

ธ

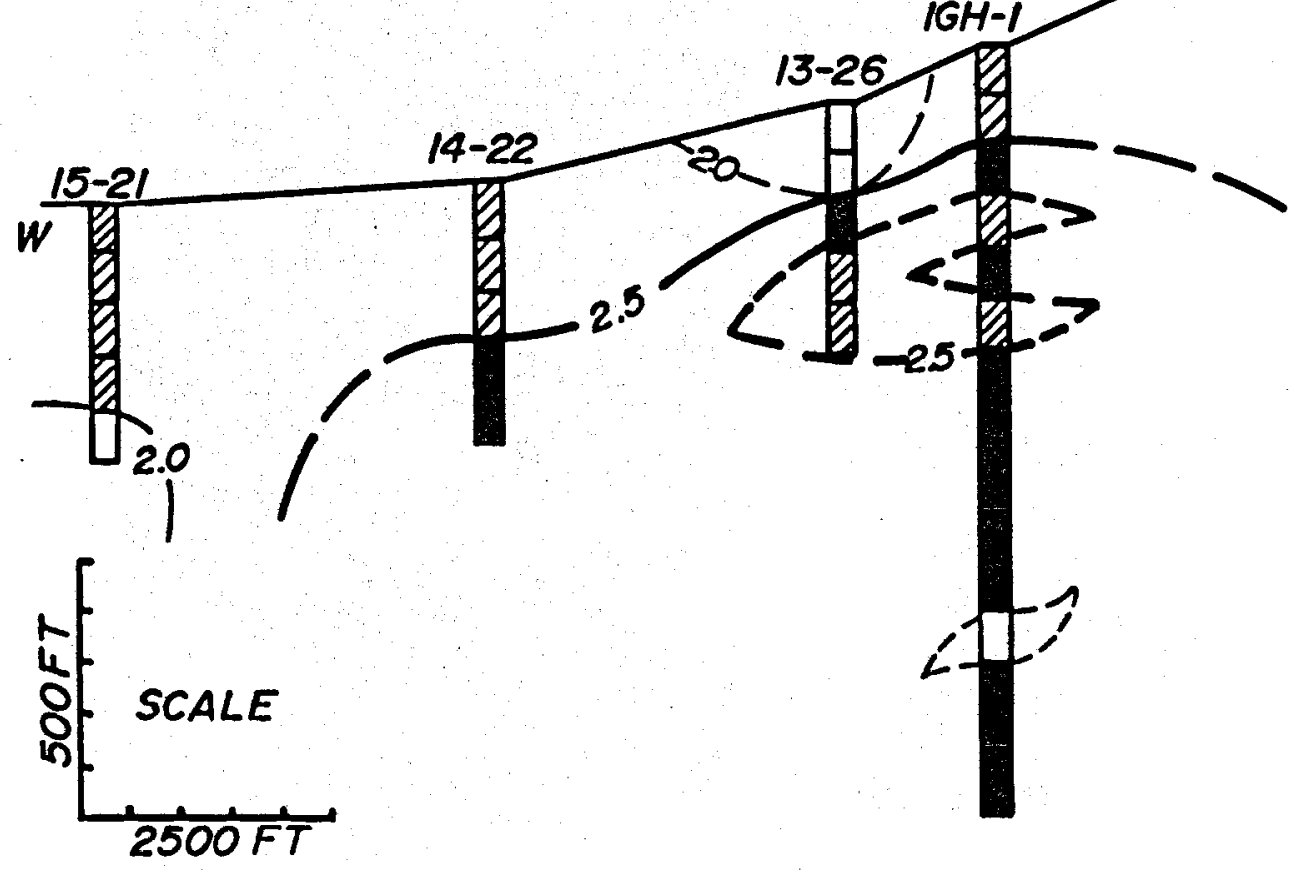

\section{BERYLLIUM}

a $>2.5 \mathrm{ppm}$

2.0-2.5ppm

$\square<2.0 \mathrm{ppm}$

Figure 13. Beryllium distribution in drill cuttings along two representative cross sections. 

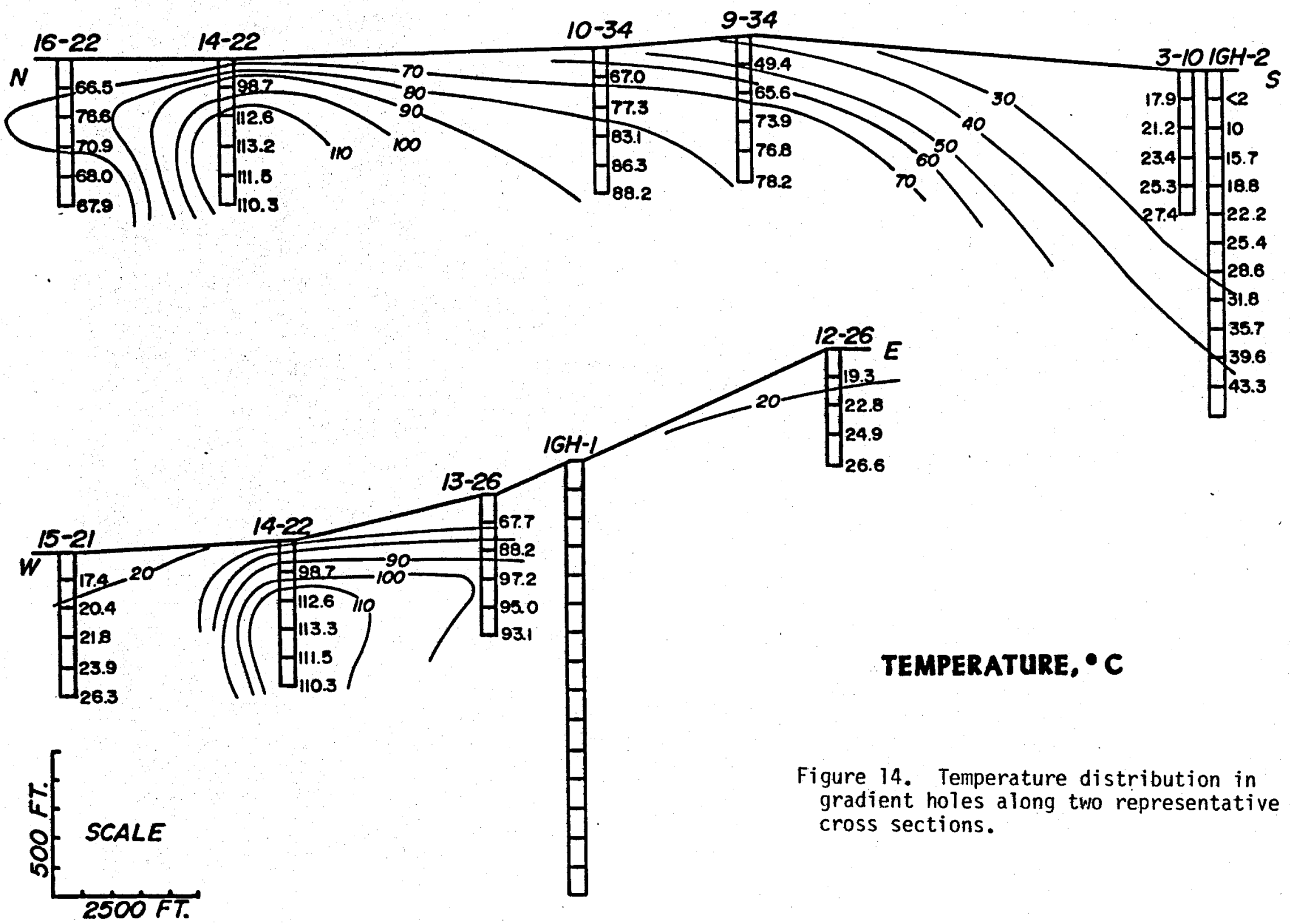

TEMPERATURE, $\bullet \mathrm{C}$

Figure 14. Temperature distribution in gradient holes along two representative cross sections. 
trations occur in the deepest samples from holes 14-22, 16-22, and 18-24. $\mathrm{Hg}$ concentrations throughout the entire prospect area are significantly greater than those observed about nongeothermal areas or widely peripheral to these areas (Capuano and Moore, 1980; Glenn and others, 1980). Statistical evaluation shows that $\mathrm{Hg}$ data similarly belong to two overlapping lognormal populations with different dispersions. A threshold value of $250 \mathrm{ppb}$ effectively separates values of a higher, more widely dispersed, population from values representing a inixture of the two populations below. Spatially, these anomalous $\mathrm{Hg}$ values occur above and around the highest As values and the highest measured temperatures.

A similar distribution pattern of $\mathrm{As}$ and $\mathrm{Hg}$ is observed at Roosevelt Hot Springs, Utah. The observed distributions and heating experinents indicate that $\mathrm{Hg}$ remobilization occurs at temperatures as low as $200^{\circ}-250^{\circ} \mathrm{C}$ and that the distribution of $\mathrm{Hg}$ peripheral to the themal center is largely produced by the present thermal configuration (Christensen and others, 1980b). The restricted peripheral concentration of $\mathrm{Hg}$ observed at Colado is also probably temperature controlled and suggests that temperatures present at the base of the $\mathrm{Hg}$ anomaly at the time of its development may have approached $200^{\circ} \mathrm{C}$.

Li data show less conclusive evidence of distinct statistical populations, and a less definitive spatial distribution. Higher concentrations are in general located within the alluvium, and may, especially in the 200-300 foot $(60-90 \mathrm{~m})$ depth interval, reflect the lateral flow of thermal fluid toward the southwest within a shallow groundwater aquifer. The high Li concentrations observed in the alluvium could also in part reflect the contribution 
of detrital siliceous volcanic materal. The consistently greater concentrations about the higher temperature locations though strongly support the relationship between thermal fluid flow and Li enrichment.

Be concentration values similarly appear to belong to two overlapping but distinct lognormal populations. The greater concentrations occur in holes 13-26 and 14-22, and in the two intermediate-depth gradient holes, coincident with the thermal anomaly at shallow levels and apparently increasing with depth.

The distributions of these four elements appear to be remarkably coincident. All are enriched within the area near drill hole 14-22 and exhibit systematic reduction away from this area. This is especially evident in the data from 200-400 ft. $(60-120 \mathrm{~m})$ (Figs. $5-8)$. These patterns are completely consistent with the measured temperature distribution at colado and reflect the configuration of active, near-surface fluid pathways in a hot-water geothermal system. These data suggest that thermal fluids rise through the alluvium in the vicinity of gradient hole 14-22 to depths of 200-400 feet $(60-120 \mathrm{~m})$, then flow laterally to the southwest within alluvial aquifers down the hydrologic gradient, probably mixing with cooler groundwaters in the process. As the fluids cool, $\mathrm{Li}, \mathrm{BE}, \mathrm{As}$, and $\mathrm{Hg}$ are deposited in response to the changing physical and cherical conditions. As and Be appear to be deposited in higher temperature zones; Li begins to deposit early but forms a rather dispersed geochemical anomaly about the system; $\mathrm{Hg}$ is anomalously high throughout the entire geothermal area but is concentrated in a shallow halo above the As and Be anomalies. This configuration is similar to that observed 
about the Roosevelt Hot Springs thermal area, Utah (Christensen and others, 1980b) .

The observed distributions of temperature, As, $\mathrm{Hg}, \mathrm{Li}$ and Be reflect the form of fluid flow paths, and appear to be largely independent of lithochemical effects. The prominent $\mathrm{Hg}$ concentration $(750 \mathrm{ppb})$ occurring in the lowermost interval in $\mathrm{IGH}-2$ may reflect $\mathrm{Hg}$ deposition from thermal waters flowing along a permeable zone at the base of the alluvial section.

Structurally, the area between drill holes 13-26 and 14-22 appears to be a critical area. The mapped geology (Johnson, 1977; sibbett and Bullett, 1980) and available gravity data (Claren Mackelprang, personal comnunication) suggest that one of the Basin and Range faults bounding the western margin of the West Humboldt Range passes between the two holes and abruptly changes trend in this area. The apparent structural intersection may form a favorable conduit for the conduction of thermal fluids into the shallow permeable alluvium. Prominent $A s$ and Be concentrations mark the position of shallow thermal fluid flow in the vicinity of drill hole 14-22. The extension of the anomalous $\mathrm{Hg}$ concentrations eastward from the most prominent As anomaly suggests that the thermal anomaly may extend this direction as well.

\section{Other Element Distributions}

There are a number of elements in addition to $\mathrm{As}, \mathrm{Hg}, \mathrm{Li}$, and Be which are known to be mobile in geothermal fluids (Ellis and Mahon, 1977; Ellis, 1979; Weisberg and others, 1979) and can be redistributed within a geothermal system through water-rock interaction. It is entirely possible and expected that one or more other elements could prove useful in other geothermal areas. 
In the Colado area, however, other possible elemental distributions related to geothermal processes either are obscured by geochemical distributions forned during other geologic events, or are developed at concentration levels below the detection limits of the analytical methods employed.

Although several of the major elements, particularly the alkali and alkaline earth metals, are commonly present in significant concentrations in thermal fluids, their redistribution within the rocks resulting from interaction with these fluids is masked by the greater variability due to lithologic differences between samples. Elements for which this is true in the Colado area include $\mathrm{Na}, \mathrm{K}, \mathrm{Ca}, \mathrm{Mg}, \mathrm{Fe}, \mathrm{Al}, \mathrm{Si}, \mathrm{Ti}, \mathrm{P}, \mathrm{Sr}, \mathrm{Ba}$, and $\mathrm{Mn}$.

Another group of elements are of limited value in this area due to their low concentrations and uncertainties associated with the preparation and analysis of samples. Elements present largely or entirely at concentrations lower than the limits of determination of the ICPQ (Christensen and others, 1980a) include: $\mathrm{V}, \mathrm{Mo}, \mathrm{Pb}, \mathrm{Th}, \mathrm{Ag}, \mathrm{Au}, \mathrm{Bi}, \mathrm{U}$, and Te. Three other elements of limited value due to loss or contamination during preparation and analysis include Si (lost during HF sample digestion), W (contamination introduced from WC mill used for sample comminution), and B (contamination introduced frorn borosilicate glass in the ICPQ).

Evaluation of geochemical data by cumulative probability plots permits rapid discrimination between elemental distributions belonging to a simple statistical population and mixed distributions of two or more populations. The numerical variability of a number of elements in this study, when evaluated in this manner, is found to be consistent with the variability 
expected within a single lognormal population. The apparently random spatial distribution of extreme high and low values for these elements further supports this suggestion. Elements in the Colado area which belong to a single background geochemical population and are evidently not significantly redistributed by geothermal processes include $\mathrm{Ba}, \mathrm{Cu}, \mathrm{Mn}, \mathrm{Sr}, \mathrm{Fe}, \mathrm{Cr}, \mathrm{Ni}, \mathrm{Pb}$, Sn, La, and Ce.

The numerical distributions of a number of other elements are polymodal. Their distributions, however, are clearly related to the lithologic variability of samples and the influence of other geolagic processes. $\mathrm{Zn}, \mathrm{Cu}$, and $C d$ in particular are present in greater concentrations in the dark-colored Mesozoic argillites and slates, whereas $\mathrm{Zr}$ is relatively less abundant in these rocks than in the overlying alluvial material. Apparent spatial zoning of these elements is due simply to the distribution of lithologies intersected in the drill holes. Sb and Au are largely present in concentrations well below the limits of the analytical procedure but occur in anomalously great concentrations in a few isolated alluvial sample intervals. This is attributable to the likely presence of detrital material within alluvium from the $\mathrm{Sb}$ and $\mathrm{Au}$ deposits in the West Humboldt Range to the east. Similarly, Co is irregularly enriched in samples from the vicinity of the mineral deposits as well as in alluvium. The polymodal distributions of these elements are related to the combined effects of multiple geochemical and geologic events and not apparently to redistribution by the present geothermal system.

\section{CONCLUSIONS}

Analysis of cuttings from 18 shallow temperature gradient drill holes and from two intermediate depth gradient holes within the Colado geothermal area 
outlines an area of anomalous geochemistry spatially coincident with an area of anomalously high measured temperatures. Both are apparently related to the shallow flow of geothermal fluids. As these thermal fluids interact with rock material, $\mathrm{Li}, \mathrm{As}, \mathrm{Be}$, and $\mathrm{Hg}$ deposit in a characteristically zoned sequence.

In the Colado area, fluids appear to rise to shallow levels near drill hole 14-22, perhaps along permeable zones resulting from the intersection of deep structures. As the fluids enter the alluvium, they apparently flow southwestward within shallow aquifers down the local hydrologic slope. Increased temperatures and enhanced concentrations of $\mathrm{As}, \mathrm{Li}, \mathrm{Be}$, and $\mathrm{Hg}$ mark the course of fluid flow. Anomalously high concentrations of $\mathrm{Hg}$ at the base of the alluvium suggest that significant flow occurs along this interface.

The distributions observed suggest that the discharge of thermal fluids from depth into the alluvium is spatially restricted to a small area in the vicinity of gradient hole $14-22$ (S22, T28N, R32E). The larger area of the observed thermal anomaly and of known thermal wells is due to pluming of warm fluid within shallow aquifers.

\section{ACKNOWLEDGEMENTS}

Analytical work was performed by Ruth Kroneman with the assistance of Tina Cerling and Bev Miller. As director of the ESL geochemical program, Joe Moore provided encouragement and constructive criticism throughout the study. Discussions with Bruce Sibbett and Claren Mackelprang clarified interpretation of the geology and geophysics of the Colado area. Critical manuscript reviews by Joe Moore, Howard Ross, Ted Glenn, and Jim Stringfellow are appreciated. 
Funding for this work was provided by the United States Department of Energy, Division of Geothermal Energy to the Earth Science Laboratory under contract number DE-AC07-80ID12079. 


\section{REFERENCES}

Bamford, R. W., 1978, Geochemistry of solid materials from two U.S. geothermal systems and its application to exploration: Univ. of Utah Research Institute, Earth Science Laboratory Rept. 6, 196 p.

Bamford, R. W., and Christensen, 0. D., 1979, Multielement geochemical exploration data for the Cove Fort-Sulphurdale Known Geothermal Resource Area, Beaver and Millard Counties, Utah: Univ. of Utah Research Inst., Earth Science Laboratory Rept. 19, 17 p.

Bamford, R. W., Christensen, 0. D., and Capuano, R. M., 1980, Multielement geochemistry of solid materials in geothermal systems and its applications. Part I: The hot-water system at the Roosevelt Hot Springs KGRA, Utah: Univ. of Utah Research Inst., Earth Science Laboratory Rept. 30 , $168 \mathrm{p}$.

Capuano, R. M. and Moore, J. N., 1980, Hg and As soil geochemistry as a technique for mapping permeable structures over a hot-water geothermal system: Geol. Soc. America Abstracts with Programs, v. 12, p. 269.

Christen, D. G., 1920, Report of land examiner on Sec. 27, T. 28N, R. 32E, MDM: Southern Pacific Company report (unpublished).

Christensen, 0. D., Kroneman, R. L., and Capuano, R. M., 1980a, Multielement analysis of geologic materials by inductively coupled plasma-atomic emission spectroscopy: Univ. of Utah Research Inst., Earth Science Laboratory Rept. 32, $33 \mathrm{p}$.

Christensen, 0. D., Moore, J. N., and Capuano, R. M., 1980b, Trace element geochemical zoning in the Roosevelt Hot Springs thermal area, Utah: Geothermal Resources Council Transactions, v. 4 (in prep.).

Cohen, P., 1964, Prel iminary results of hydrogeologic investigations in Valley of the Humboldt River near Winnemucca, Nevada: United States Geological Survey Water Supply Paper 1754, 59 p.

Cohen, P., 1966, Water in the Humboldt River Valley near Winnemucca, Nevada: United States Geological Survey Water Supply Paper 1816, 69 p.

Coonrad, W. L., 1957, Geology and mineral resources of Township 27 North, Ranges 31,32 and 33 East, Mount Diablo Meridian, Pershing County, Nevada: Southern Pacific Company Report (unpublished), $43 \mathrm{p}$.

Ellis, A. J., 1979, Explored Geothermal Systems in Barnes, H. L., Geochemistry of Hydrothermal Ore Deposits: New York, John Wiley and Sons.

Ellis, A. J., and Mahon, W. A. J., 1977, Chemistry and Geothermal Systems: New York, Academic Press, 392 pages. 
Glenn, W. E., Chapman, D. S., Foley, D., Capuano, R. M., Sibbett, B. S., Cole, D., and Ward, S., 1980, Geotherinal exploration at Hill Air Force Base, Ogden, Utah: Univ. of Utah Research Inst., Earth Science Laboratory Rept. $34,77 \mathrm{p}$.

Johnson, M. G., 1977, Geology and mineral deposits of Pershing County, Nevada: Nevada Bureau of Mines and Geology Bulletin 89, $115 \mathrm{p}$.

Lepeltier, C., 1969, A simplified statistical treatment of geochemical data by graphical representation: Economic Geology, v. 64, p. 538-550.

Osterling, W. A., 1960, Geology and mineral resources of Township 28 North, Ranges 31 and 32 East, Mount Diablo Meridian, Pershing County, Nevada: Southern Pacific Company report (unpublished), $23 \mathrm{p}$.

Sibbett, B. S., and Bullett, M. J., 1979, Lithology of 18 shallow thermal gradient holes, Colado area, Nevada: Univ. of Utah Research Inst., Earth Science Laboratory open-file release, $7 \mathrm{p}$.

Sibbett, B. S. and Bullett, M. J., 1980, Geology of the Colado geothermal area, Pershing County, Nevada: Univ. of Utah Research Inst., Earth Science Laboratory Report (in prep.).

Sinclair, A. J., 1974, Selection of threshold values in geochemical data using probability graphs: Jour. Geochemical Exploration, v. 3, p. 129-149.

Sinclair, A. J., 1976, Applications of probability graphs in mineral exploration: Association of Exploration Geochemists Special Volume no. 4, $95 \mathrm{p}$.

Weissberg, B. G., Brown, P. R. L., and Seward, T. M., 1979, Ore metals in active geothermal systems in Barnes, H. L., Geochemistry of Hydrothermal Ore Deposits: New York, John Wiley and Sons. 


\section{APPENDIX}

Summary of Geochemical Data

\begin{tabular}{|c|c|c|c|c|}
\hline Element & Minimum & Maximum & Mean & Standard Deviation \\
\hline$\overline{\mathrm{Na}, \mathrm{ppm}}$ & 340 & 29800 & 8410 & 6670 \\
\hline $\mathrm{K}, \mathrm{ppm}$ & 9120 & 34600 & 21000 & 6220 \\
\hline $\mathrm{Ca}, \mathrm{ppm}$ & 2190 & 132000 & 52400 & 25200 \\
\hline $\mathrm{Mg}, \mathrm{ppm}$ & 1830 & 59900 & 10300 & 8010 \\
\hline $\mathrm{Fe}, \mathrm{ppm}$ & 9970 & 40500 & 22600 & 6550 \\
\hline $\mathrm{Al}, \mathrm{ppm}$ & 32500 & 84700 & 56400 & 11000 \\
\hline $\mathrm{Ti}, \mathrm{ppm}$ & 1260 & 3250 & 2180 & 443 \\
\hline $\mathrm{p}, \quad \mathrm{ppm}$ & 413 & 3420 & 956 & 563 \\
\hline $\mathrm{Sr}, \mathrm{ppm}$ & 19 & 428 & 189 & 111 \\
\hline $\mathrm{Ba}, \mathrm{ppm}$ & 262 & 2890 & 969 & 786 \\
\hline $\mathrm{V}, \mathrm{ppm}$ & $<150$ & $<150$ & $<150$ & - \\
\hline $\mathrm{Cr}, \mathrm{ppm}$ & 12 & 72 & 38 & 12 \\
\hline $\mathrm{Mn}, \mathrm{ppm}$ & 45 & 1180 & 388 & 173 \\
\hline $\mathrm{Co}, \mathrm{ppm}$ & 13 & 875 & 41 & 83 \\
\hline $\mathrm{Ni}, \mathrm{ppm}$ & 8 & 50 & 24 & 8 \\
\hline $\mathrm{Cu}, \mathrm{ppm}$ & 9 & 279 & 28 & 26 \\
\hline Mo, $\mathrm{ppm}$ & $<50$ & $<50$ & $<50$ & 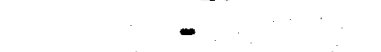 \\
\hline $\mathrm{Pb}, \mathrm{ppm}$ & $<10$ & 37 & - & 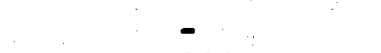 \\
\hline $\mathrm{Zn}, \mathrm{ppm}$ & 33 & 2000 & 150 & 219 \\
\hline $\mathrm{cd}, \mathrm{ppm}$ & $<5$ & 10 & . & - \\
\hline $\mathrm{Ag}, \mathrm{ppm}$ & $<2$ & 20 & - & - \\
\hline $\mathrm{Au}, \mathrm{ppm}$ & $<4$ & 7 & 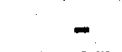 & \\
\hline As, $\mathrm{ppm}$ & 9 & 275. & 47 & 49 \\
\hline $\mathrm{Sb}, \mathrm{ppm}$ & $<30$ & 173 & - & - \\
\hline $\mathrm{Bi}, \mathrm{ppm}$ & $<100$ & $<100$ & $<100$ & - \\
\hline U, ppm & $<2000$ & $<2000$ & $<2000$ & - \\
\hline $\mathrm{Te}, \mathrm{ppm}$ & $<50$ & $<50$ & $<50$ & - \\
\hline $\mathrm{Sn}, \mathrm{ppm}$ & $<5$ & 25 & - & - \\
\hline $\mathrm{Li}, \mathrm{ppm}$ & 20 & 96 & 48 & 32 \\
\hline $\mathrm{Be}, \mathrm{ppm}$ & 1.5 & 3.0 & 2.1 & 0.3 \\
\hline $\mathrm{Zr}, \mathrm{ppm}$ & 11 & 107 & 56 & 25 \\
\hline $\mathrm{La}, \mathrm{ppm}$ & 14 & 33 & 22 & 11 \\
\hline $\mathrm{Ce}, \mathrm{ppm}$ & 23 & 57 & 40 & 9 \\
\hline Th, ppm & $<150$ & $<150$ & $<150$ & - \\
\hline $\mathrm{Ha}, \mathrm{ppb}$ & 10 & 3300 & 265 & 417 \\
\hline
\end{tabular}

As determined colorimetrically, $\mathrm{Hg}$ by gold film detector, all other elements by ICPQ.

Si lost during sample digestion; $W$ and $B$ contamination during sample preparation and analysis. 